Annotations in Scholarly Editions and Research 



\section{Annotations in Scholarly Editions and Research}

Functions, Differentiation, Systematization

Edited by Julia Nantke and Frederik Schlupkothen

\section{DE GRUYTER}


Funded by the Fritz Thyssen Foundation

ISBN 978-3-11-063601-7

e-ISBN (PDF) 978-3-11-068911-2

e-ISBN (EPUB) 978-3-11-068917-4

DOI https://doi.org/10.1515/9783110689112

\section{(cc) BY-NC-ND}

This work is licensed under the Creative Commons Attribution-NonCommercialNoDerivatives 4.0 International License. For details go to http://creativecommons.org/ licenses/by-nc-nd/4.0/.

\section{Library of Congress Control Number: 2020942012}

\section{Bibliographic information published by the Deutsche Nationalbibliothek}

The Deutsche Nationalbibliothek lists this publication in the Deutsche Nationalbibliografie; detailed bibliographic data are available on the Internet at http://dnb.dnb.de.

(C) 2020 Julia Nantke and Frederik Schlupkothen, published by Walter de Gruyter GmbH, Berlin/Boston.

The book is published with open access at www.degruyter.com.

Cover image: Michael Ruml, Bergische Universität Wuppertal

Typesetting: Michael Ruml and Frederik Schlupkothen, University of Wuppertal Printing and binding: $\mathrm{CPI}$ books $\mathrm{GmbH}$, Leck.

www.degruyter.com 